Rocznik Przektadoznawczy $10 \stackrel{\text { : }}{\mathrm{N}}$ ISSN 1896-4362

\title{
Marta Kaźmierczak, Przekład w kręgu intertekstualności, Instytut Lingwistyki Stosowanej UW, Warszawa 2012, 273 strony (recenzja książki)
}

DOI: http://dx.doi.org/10.12775/RP.2015.019

Wymieniony w tytule krąg okazuje się zapowiedzią kolejnych. W książce bowiem mamy do czynienia z klasyfikacją intertekstów przedstawioną na zasadzie koncentrycznie zacieśniających się kręgów (zob. s. 5), od paneuropeizmów do autonawiązań. Celem recenzowanej monografii jest zbadanie związku pomiędzy typem intertekstu (przynależności do danej grupy) a stopniem jego przekładalności, z uwzględnieniem przestrzeni kulturowej (tłumaczenie na języki bliskopokrewne i dalekie). Mimo wzrostu zainteresowania w ostatnich latach intertektualnością w kontekście przekładu nie była dotąd podejmowana - jak podkreśla też autorka - taka właśnie, tematyczna klasyfikacja nawiązań międzytekstowych (zob. s. 5). Materiałem ilustracyjnym jest poezja Bolesława Leśmiana': korpus translatów składa się w zasadniczej mierze z przekładów na język rosyjski i angielski, często jednak wzbogacany tłumaczeniami na język niemiecki, czeski, bułgarski i ukraiński. Skupienie się na wierszach jednego poety gwarantuje spójny zbiór tekstów, wybór zaś poezji pozwala oczekiwać innych rozwiązań translatorskich niż połączenie przekładu dosłownego z przypisem, z czym moglibyśmy mieć do czynienia w przypadku prozy (zob. s. 6).

Przedstawiony $\mathrm{w}$ książce model analityczny polega na wskazywaniu przez autorkę sygnałów intertekstualności w oryginale, odnajdywaniu i omawianiu odnośnych miejsc w przekładach, rozważaniu innych możliwości translacyjnych, a wreszcie badaniu wpływu zastosowanych decyzji na odbiór intertekstu w przekładzie. Autorka oczywiście sprawdza też obecność i funkcjonowanie rozpatrywanego intertekstu w kulturze przekładu oraz zwraca uwagę na fakt użycia/braku użycia przez tłumaczy wierszy Leśmiana istniejących rozwiązań.

${ }^{1}$ Oparcie się na utworach Bolesława Leśmiana autorka uzasadnia z jednej strony szerokim wachlarzem występujących w nich międzytekstowych nawiązań, z drugiej zaś - dostępem do względnie bogatego korpusu przekładów, w tym serii translatorskich. 
Praca składa się z trzech zasadniczych części. Pierwszą z nich tworzą Preliminaria (s. $8-42^{2}$ ). W nich autorka w bardzo rzetelny sposób przedstawia historię przekładów oraz odbiór polskiego poety za granicą (Przekłady i zagraniczna recepcja poezji Leśmiana). Nie pomija przy tym tłumaczeń amatorskich zamieszczanych w Internecie, jednocześnie każdorazowo zaznacza, czy będzie z nich korzystać, czy nie, oraz motywuje swój wybór (zob. np. przyp. 19 na s. 11 lub rozważania na s. 16). Kolejne trzy podrozdziały dotyczą stanu badań nad intertekstualnością (Perpektywa badawcza), intertekstualnością z perspektywy przekładu (Intertekstualność a przekład) i źródłami Leśmianowskich odniesień (Intertekstualność w pracach o twórczości Leśmiana). Przy okazji szeroko zarysowanej literatury przedmiotu (należy podkreślić, że nie jest to tylko przegląd, ale również próba krytycznego spojrzenia) autorka zwraca uwagę na te prace, na które będzie się powoływać w dalszej części swych rozważań, przedstawia też narzędzia badawcze, a także wybrany zbiór terminologiczny (sygnał intertekstualny/wykładnik intertekstualny/intertekst, źródło intertekstu/archetekst/pre-tekst; w przypadku oryginału i przekładu: tekst źródłowy-tekst docelowy; zob. s. 21). Preliminaria kończy szkic dotyczący recepcji przekładów w odnośnych kulturach docelowych, autokomentarzy tłumaczy oraz komentarzy redaktorów poszczególnych wydań, recenzentów czy badaczy zajmujących się obcojęzycznymi wariantami wierszy Leśmiana (Badania nad przekładami poezji Leśmiana). Na tle zaprezentowanych szczegółowych studiów i uwag (nielicznych, zwłaszcza w przypadku angielskich tłumaczeń) monografia Marty Kaźmierczak stanowi niejako przy okazji ważny element podsumowujący ogólną problematykę tłumaczenia utworów polskiego poety.

Głównym jednak zadaniem pracy jest prześledzenie odwołań intertekstualnych w parze oryginał-przekład. Temu poświęcone zostały dwa kolejne rozdziały: Interteksty o wysokim stopniu eksplicytności (s. 43-52) oraz Kręgi intertekstualności (Typy pre-tekstów a przekład) (s. 53-232). Pierwszy z nich, zdecydowanie odbiegający objętościowo od drugiego, stanowi wstępne rozpoznanie tematu i dotyczy wpływu jawności intertekstu na jego odtworzenie w przekładzie. Jawność wykładnika intertekstualnego może wynikać przede wszystkim z zastosowania wyróżnienia topograficznego (cudzysłów, rozstrzelony druk) lub atrybucji (wskazanie źródła bądź sugestia zapożyczenia). Krótkie rozważania w obrębie tego zagadnienia zamyka ocena przedstawionych spostrzeżeń. W rozdziale trzecim skupiono się na różnych poziomach

${ }^{2}$ Na s. 42 zamieszczony został wykaz stosowanych skrótów. 
funkcjonowania archetekstu. Tu autorka dzieli swój wywód na 10 części³, stanowiących kolejne podrozdziały:

1. Nawiazania o charakterze biblijnym

2. Nawiazania antyczne

3. Odwołania do kanonu literatury powszechnej

4. Baśń literacka a archetekst

5. Literatura $i$ wierzenia Indii jako archetekst

6. Interteksty o charakterze filozoficznym

7. Nawiązania do makrotekstur mitologii słowiańskiej

8. Nawiazania do literatury polskiej

9. Intertekstualne nawiazania do polskiego folkloru

10. Autonawiazania.

Nie będę w tym miejscu omawiać każdego z wymienionych wątków, chciałabym natomiast podzielić się kilkoma ogólnymi spostrzeżeniami. Do nich należy przede wszystkim wnikliwa znajomość twórczości Leśmiana która pozwala autorce na rzetelną analizę badanego materiału, doskonała kompetencja językowa (ilustracje pochodzą z różnych - wymienionych wcześniej - językowych źródeł), niezbędna z jednej strony do oceny przedstawionych decyzji translatorskich, $\mathrm{z}$ drugiej zaś - do sugerowania własnych rozwiązań oraz doskonała orientacja w zagadnieniach przekładoznawczych (wielokrotnie wspomniany $\mathrm{w}$ tekście głównym problem zyskuje rozwinięcie w ramach przypisu uzupełnionego odpowiednią bibliografią). Na uwagę zasługuje skrupulatność badawcza, ujawniająca się w szczegółowym dokumentowaniu założonych tez, stawianiu nowych pytań, szukaniu na nie odpowiedzi w różnych źródłach. Warta podkreślenia jest też pozytywnie wartościowana rezerwa interpretacyjna, czyli wskazywanie na możliwość rozmaitych uzasadnień analizowanych rozwiązań przekładowych. Przy tej okazji wypływa

${ }^{3}$ Spojrzenie tematyczne zaprezentowane w tym rozdziale nie oznacza opozycji w stosunku do poprzedzającej go części. Intertekstualność ujawniać mogą nie tylko wskazówki graficzne czy obecna w tekście atrybucja, ale też niektóre nazwy własne.

${ }^{4}$ Rozważania na temat poezji Leśmiana w kontekście przekładu były tematem m.in. następujących artykułów autorki: „Kłopoty ze wzniosłością - Leśmian po rosyjsku i po angielsku", [w:] Między oryginatem a przektadem, t. XIV: Wzniostość i styl wysoki w przektadzie, J. Brzozowski, M. Filipowicz-Rudek (red.), Kraków 2008, s. 103-117; „Leśmian ocenzurowany?", [w:] Tabu w przekładzie, P. Fast, N. Strzelecka (red.), Katowice-Częstochowa 2007, s. 145-169; „Wybrane parateksty obcojęzycznych wydań poezji Bolesława Leśmiana”, [w:] Między oryginatem a przektadem, t. XVII: Parateksty przektadu, E. Skibińska (red.), Kraków 2011, s. 149-164; „О необходимости словотворческой изобретательности в переводе (Б. Лесьмян и Г. Зельдович)", [w:] Концептосфера - дискурс - картина мира. Международный сборник научных трудов по лингвокультурологии, СаГа, Самара 2006, s. 148-153. 
na powierzchnię chociażby wątek wyczerpywania się serii w tłumaczeniach poetyckich związany z ryzykiem popełnienia plagiatu (zob. s. 60). Oceniając monografię, należy ponadto odnotować fakt sięgnięcia przez autorkę również po pozawerbalne sygnały intertekstualne - w jednym $\mathrm{z}$ podrozdziałów przedstawia bowiem zagadnienie najtrudniejszej do odtworzenia aluzji, jaką jest rysunek rytmiczny (metrum w roli intertekstu - zob. s. 210 i n.).

Oprócz konkluzji, zamykających poszczególne kręgi intertekstualnych odniesień, autorka prezentuje też kompleksowe podsumowanie przeprowadzonych badań (Wnioski, s. 233-239). Perspektywa całości przekłada się na przedstawienie ogólnego bilansu zysków i strat oraz - tam, gdzie jest to możliwe - strategii poszczególnych tłumaczy. Monografię zamyka bogata bibliografia oraz indeks nazwisk, ułatwiający późniejsze wyrywkowe korzystanie z książki.

Omówienie pracy Marty Kaźmierczak byłoby niepełne bez wspomnienia o walorach językowych. Autorka bowiem nie tylko kreśli szeroki i jednocześnie szczegółowy obraz badawczy, ale czyni to jeszcze z ogromną dbałością o szatę językową. Wszystko to w połączeniu ze swobodą wypowiedzi i płynnym przechodzeniem do kolejnych rozważań sprawia, że tę książkę, ważną $\mathrm{z}$ naukowego punktu widzenia, po prostu dobrze się czyta.

Monika Krajewska (Uniwersytet Mikołaja Kopernika w Toruniu) 